\title{
Valonea Tannin: Tyrosinase Inhibition Activity, Structural Elucidation and Insights into the Inhibition Mechanism
}

\author{
Jiaman Liu ${ }^{1}$, Yuqing Liu ${ }^{1}$, Xiaofeng He ${ }^{1}$, Bo Teng ${ }^{1,2, *(\mathbb{C} \text { and Jacqui M. McRae }}{ }^{3}$ \\ 1 College of Science, Shantou University, Shantou 515063, China; 19jmliu1@stu.edu.cn (J.L.); \\ 15yqliu2@stu.edu.cn (Y.L.); 19xfhe@stu.edu.cn (X.H.) \\ 2 Guangdong Provincial Key Laboratory of Marine Biotechnology, Shantou University, Shantou 515063, China \\ 3 School of Chemical Engineering and Advanced Materials, The University of Adelaide, \\ Adelaide, SA 5005, Australia; jacqui.mcrae@adelaide.edu.au \\ * Correspondence: bteng@stu.edu.cn
}

check for

updates

Citation: Liu, J.; Liu, Y.; He, X.; Teng, B.; McRae, J.M. Valonea Tannin: Tyrosinase Inhibition Activity, Structural Elucidation and Insights Into the Inhibition Mechanism Molecules 2021, 26, 2747. https:// doi.org/10.3390/molecules26092747

Academic Editors: Manuela Pintado, Ezequiel Coscueta and Maria Emilia Brassesco

Received: 14 April 2021

Accepted: 5 May 2021

Published: 7 May 2021

Publisher's Note: MDPI stays neutral with regard to jurisdictional claims in published maps and institutional affiliations.

Copyright: (c) 2021 by the authors. Licensee MDPI, Basel, Switzerland. This article is an open access article distributed under the terms and conditions of the Creative Commons Attribution (CC BY) license (https:/ / creativecommons.org/licenses/by/ $4.0 /)$.

\begin{abstract}
Valonea tannin is a natural product readily extracted from acorn shells that has been suggested to have potential skin whitening properties. This study investigated the tyrosinase inhibition activity of extracted valonea tannin and the associated structure-function activity. Nuclear magnetic resonance spectroscopy and molecular weight analysis with gel permeation chromatography revealed that valonea tannin could be characterized as a hydrolysable tannin with galloyl, hexahydroxydiphenoyl and open formed-glucose moieties and an average molecular weight of $3042 \pm 15$ Da. Tyrosinase inhibition assays demonstrated that valonea tannin was 334 times more effective than gallic acid and 3.4 times more effective than tannic acid, which may relate to the larger molecular size. Kinetic studies of the inhibition reactions indicated that valonea tannin provided tyrosinase inhibition through mixed competitive-uncompetitive way. Stern-Volmer fitted fluorescence quenching analysis, isothermal titration calorimetry analysis and in silico molecule docking showed valonea tannin non-selectively bound to the surface of tyrosinase via hydrogen bonds and hydrophobic interactions. Inductively coupled plasma-optical emission spectroscopy and free radical scavenging assays indicated the valonea tannin had copper ion chelating and antioxidant ability, which may also contribute to inhibition activity. These results demonstrated the structure-function activity of valonea tannin as a highly effective natural tyrosinase inhibitor that may have commercial application in dermatological medicines or cosmetic products.
\end{abstract}

Keywords: valonea tannin; hydrolysable tannin; tyrosinase; enzyme binding; enzyme inhibition; inhibition mechanism

\section{Introduction}

Valonea tannin is a hydrolysable tannin [1] with many uses, including as wood adhesives [2], metal chelating depressants in the mining industry [3], leather tanning or potentially as a replacement for plastics [4]. Valonea tannin is abundantly present in the acorn cups of Valonia oak (Quercus ithaburensis subsp. macrolepis (Kotschy, Hedge and Yaltirik), a common tree throughout Eurasia, and can be readily extracted using hot water [5]. These properties make it a potentially useful resource for many applications that might provide greater economic value.

Skin whitening agents are in large demand around the world with almost $15 \%$ of the human population investing in these products and the worldwide market reaching U.S. $\$ 23$ billion in 2020 [6]. These agents are commonly used to treat a range of dermatological problems caused by the over-production of melanin pigment (known as disordered melanogenesis), such as melanoma, melasma, solar lentigo, freckles, pigmented acne scars and age spots $[7,8]$. Tyrosinase is a reaction rate-limiting enzyme of melanin synthesis and is also a target enzyme for the treatment of pigmentation related disorders $[6,9,10]$. Chemicals with tyrosinase inhibition abilities, such as hydroquinone, arbutin, kojic acid, 
corticosteroids, azelaic acid and hydroxyanisole, are widely applied in medicine and cosmetics as functional ingredients $[6,9,10]$. However, application of these chemicals is often associated with drawbacks and side effects, including contact dermatitis, irritation, burning and hypochromia $[11,12]$. Thereby, finding new tyrosinase inhibitors, with effective performance but without safety issues, has become a great concern for both the medical and cosmetic industries.

Tannins are quantitatively abundant plant secondary metabolites that have protein binding capabilities. They are classified as either condensed or hydrolysable tannins depending on their molecular structure. Hydrolysable tannins are composed of glucose, galloyl, hexahydroxydiphenoyl (HHDP) and other derivatives subdivided into ellagitannin and gallotannin structures [1]. In contrast, condensed tannins (also known as proanthocyanidins) are composed of flavan-3-ol subunits which are linked by covalent bonds [13]. Condensed tannins have tyrosinase inhibition abilities which are comparable to commercial inhibitors $[14,15]$. This tyrosinase inhibition activity may be due to structural similarities between condensed tannin subunits and substrates (tyrosine and L-DOPA) (Figure 1) [15]. The mechanism of action may also be because condensed tannins behave as competitors in both L-DOPA and DOPA quinone formation processes [16].

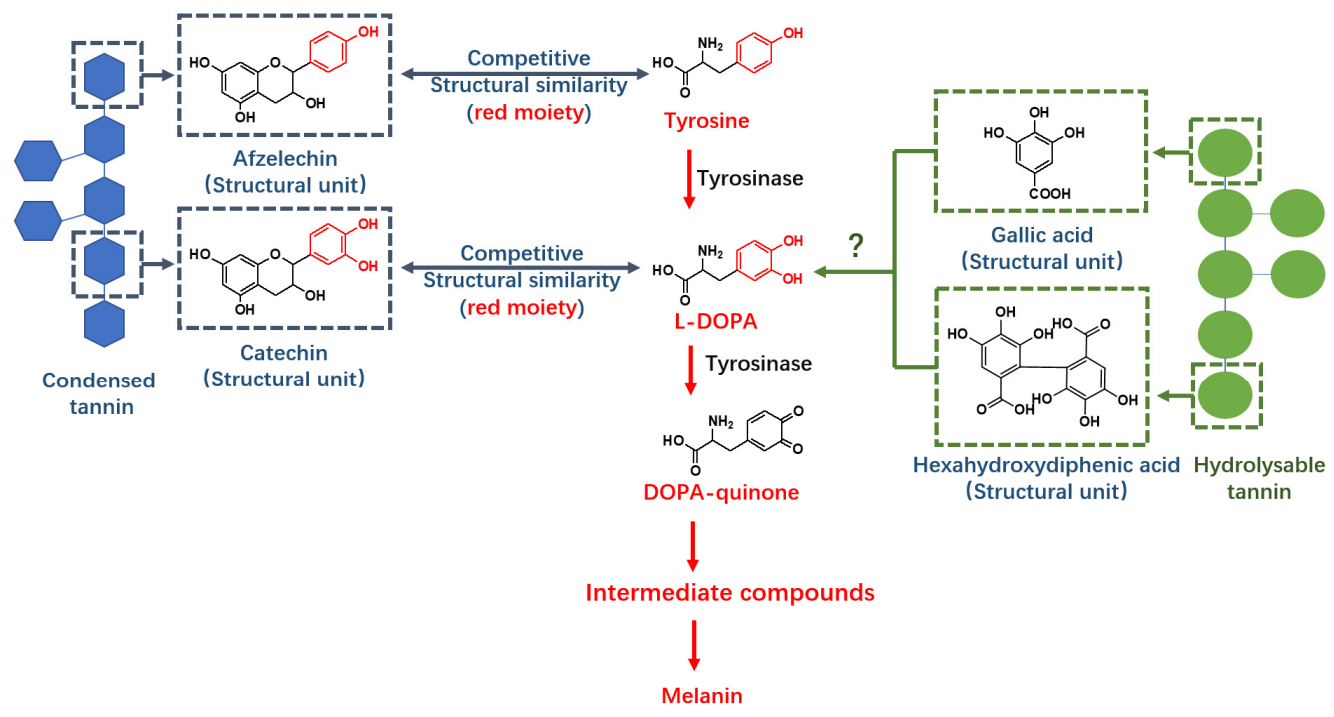

Figure 1. Condensed tannin has structural similarities with tyrosine and L-DOPA and thereby provides tyrosinase inhibition ability, but the structure of hydrolysable tannin differs from condensed tannin and its tyrosinase inhibition mechanism remains unknown.

Hydrolysable tannins may also have tyrosinase inhibition activity due to their protein binding capabilities. Previous studies have shown that the structural subunits of hydrolysable tannins, ellagic acid and gallic acid, have significant tyrosinase inhibition abilities [17]; however, the mechanism of action remains unknown. It is therefore likely that valonea tannin, a hydrolysable tannin, may exhibit tyrosinase inhibition activity, providing a novel, abundant and natural source of these important medical and cosmetic agents.

In order to provide more theoretical information about the tyrosinase inhibition ability from hydrolysable tannin, also to extend the potential application of hydrolysable tannins. In the current study, the structures of valonea tannins extracted from acorn cups were elucidated and the tyrosinase inhibition activity compared to gallic acid and tannic acid. The inhibition mechanism was explored on the aspects of: (1) inhibition kinetic analysis; (2) tyrosinase binding ability; (3) antioxidant activity; and (4) copper ion (coenzyme) chelating ability, using fluorescence quenching accompanied with Stern-Volmer fitting analysis, isothermal titration calorimetry (ITC) analysis, as well as in silico molecular docking (Autodock Vina). 


\section{Results and Discussion}

\subsection{Structure Elucidation of Valonea Tannins}

Tannin is a mixture of oligomers and polymers with similar structures and physical properties [1]. Composition of structural moieties and molecular weights were considered as crucial structural characteristics because these characters have a substantial impact on the functions of tannins [18]. The valonea tannin was purified with Sephadex LH-20 because it was proven previously that this method can eliminate the simple phenolics, proteins and polysaccharides efficiently, therefore it commonly used for tannin purification [19]. Then, valonea tannin structure was elucidated using ${ }^{13} \mathrm{C}$ NMR (Figure S1) to obtain the composition of the structural moieties. Chemical shifts were compared with those of standard tannic and gallic acids as well as those of similar moieties from previous reports [20] to give the proposed structure of valonea tannin based on the previous 1D and 2D-NMR research of ellagitannins and isolated flavonoid oligomers; resonances from 170 to $55 \mathrm{ppm}$ were assigned to the carbons on carbonyl, phenyl and alkyl moieties, respectively, and shown on Table 1.

Table 1. ${ }^{13} \mathrm{C}$ NMR chemical shifts assignment for the Valonea tannin ${ }^{1}$.

\begin{tabular}{|c|c|c|}
\hline Chemical Shift (ppm) & Assignment & Note \\
\hline \multicolumn{3}{|c|}{ Valonea tannin } \\
\hline 164.41 & C7" & Carbonyl $\mathrm{C}=\mathrm{O}, \mathrm{HHDP}$ \\
\hline 163.98 & $\mathrm{C} 7$ & Carbonyl $\mathrm{C}=\mathrm{O}$, galloyl \\
\hline 158.50 & $C 7^{\prime}$ & Carbonyl $\mathrm{C}=\mathrm{O}, \mathrm{HHDP}$ \\
\hline 144.67 & $\mathrm{C} 3$ & Phenolic $-\mathrm{OH}$, galloyl \\
\hline 143.65 & $\mathrm{C} 5, \mathrm{C}^{\prime}, \mathrm{C}^{\prime}, \mathrm{C} 3^{\prime \prime}, \mathrm{C} 5^{\prime \prime}$ & Phenolic $-\mathrm{OH}$, galloyl and HHDP \\
\hline 135.92 & $\mathrm{C} 4, \mathrm{C} 4^{\prime}, \mathrm{C} 4^{\prime \prime}$ & Phenolic -OH, galloyl and HHDP \\
\hline 123.88 & $\mathrm{C} 1, \mathrm{C} 1^{\prime}, \mathrm{C} 1^{\prime \prime}$ & Phenolic carbons, galloyl and HHDP \\
\hline 114.89 & $\mathrm{C} 2^{\prime}$ & Phenolic C-C bridges, HHDP \\
\hline 113.63 & C2" & Phenolic C-C bridges, HHDP \\
\hline 109.61 & $\mathrm{C} 2, \mathrm{C} 6$ & Phenolic carbons, Galloyl \\
\hline 70.04 & $C-5^{\prime \prime \prime}$ & Open glucose form \\
\hline 62.71 & $C-3^{\prime \prime \prime}, C-4^{\prime \prime \prime}, C-6^{\prime \prime \prime}$ & Open glucose form \\
\hline 57.40 & $\mathrm{C}-2^{\prime \prime \prime}$ & Open glucose form \\
\hline \multicolumn{3}{|c|}{ Gallic acid } \\
\hline 169.1 & C7 & Carbonyl $\mathrm{C}=\mathrm{O}$ \\
\hline 144.9 & $\mathrm{C} 3, \mathrm{C} 5$ & Phenolic-OH \\
\hline 138.2 & C4 & Phenolic-OH \\
\hline 120.5 & C1 & Phenolic carbons \\
\hline 109.0 & $\mathrm{C} 2, \mathrm{C} 6$ & Phenolic carbons \\
\hline \multicolumn{3}{|c|}{ Tannic acid } \\
\hline 169.7 & $\mathrm{C} 7$ & Carbonyl $\mathrm{C}=\mathrm{O}$ \\
\hline 165.4 & $C 7^{\prime}$ & Carbonyl $\mathrm{C}=\mathrm{O}$ \\
\hline 144.9 & $\mathrm{C} 3, \mathrm{C} 5, \mathrm{C}^{\prime}, \mathrm{C}^{\prime}$ & Phenolic-OH \\
\hline 139.2 & $\mathrm{C} 4$ & Phenolic-OH \\
\hline 138.0 & $\mathrm{C} 4^{\prime}$ & Phenolic-OH \\
\hline 121.3 & $\mathrm{C} 1, \mathrm{C}^{\prime}$ & Phenolic carbons \\
\hline 109.1 & $\mathrm{C} 2, \mathrm{C} 6, \mathrm{C}^{\prime}{ }^{\prime}, \mathrm{C}^{\prime}$ & Phenolic carbons \\
\hline 92.5 & $\mathrm{C} 1^{\prime \prime}$ & Closed glucoside \\
\hline 71.9 & $\mathrm{C} 2 "$ & Closed glucoside \\
\hline 67.1 & $\mathrm{C} 4 "$ & Closed glucoside \\
\hline 66.2 & C6" & Closed glucoside \\
\hline 63.0 & $\mathrm{C} 5^{\prime \prime}$ & Closed glucoside \\
\hline
\end{tabular}

\footnotetext{
${ }^{1}$ Spectra were applied in Figure S1, the numbering of carbons was referred to Figure 2.
} 

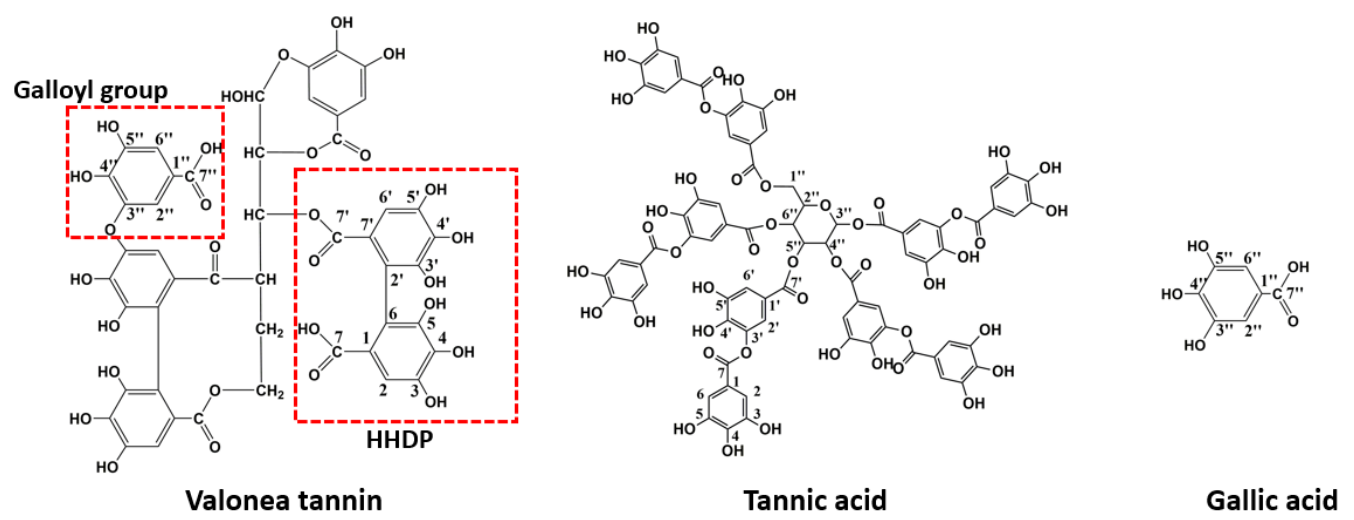

Figure 2. Example of the elucidated structure of valonea tannin, ${ }^{13} \mathrm{C}$ NMR spectra indicate that tannic acid and gallic acid were dominant moieties in valonea tannin.

Resonances from 100 to $170 \mathrm{ppm}$ were used to identify the composition of hydrolysable tannins [20]. The chemical shifts appeared at 164.41, 158.50, 114.89 and $113.63 \mathrm{ppm}$ were attributed to the carbonyl $\mathrm{C}=\mathrm{O}$ and phenolic $\mathrm{C}-\mathrm{C}$ bridges on hexahydroxydiphenoyl (HHDP) moieties [20]. These shifts can be considered as direct evidence to prove the existence of HHDP in valonea tannins. It also implied that valonea tannin belonged to the typical ellagitannin in the hydrolysable tannin family. This finding is in agreement with the report from Özgünay et al., who also found the HHDP moieties based on precursor and fragments ions in MALDI TOF MS spectrum of the valonea tannin [21].

Resonances at $163.98,144.67$ and $109.61 \mathrm{ppm}$ were attributed to the carbonyl C=O, phenolic - $\mathrm{OH}$ and phenolic carbon on galloyl moieties [20]. Similarly, these shifts can be also found in gallic acid (169.1, 144.9 and $109.0 \mathrm{ppm})$ and tannic acid (169.7, 144.9 and $109.1 \mathrm{ppm})$.

The resonances from 70 to $54 \mathrm{ppm}$, were characteristic resonances from the open glucose forms [22], while the closed glucose form (95 to $80 \mathrm{ppm}$ ) was not detected in the current study. Other resonances were attributed to the phenolic carbon linked with or without hydroxyl groups and were attributed to both HHDP and galloyl moieties [20].

These chemical shifts not only confirmed the existence of galloyl and HHDP moieties in valonea tannins, but also indicated the structural characteristics of the valonea tannins were significantly different to condensed tannins (composed of flavanol subunits) [23]. Based on the information obtained from ${ }^{13} \mathrm{C}$ NMR analysis, the typical structure of the valonea tannin was deduced and shown on Figure 2, accompanied with the structure of tannic acid and gallic acid.

Tannin molecular weight is directly related to the biochemical properties and is a crucial parameter for protein interaction and enzyme inhibition [15]. Determining the average molecular weight of a tannin can also assist in elucidating the average size of the tannins $[15,18]$. The molecular weight distribution of the isolated valonea tannin was analysed using gel permeation chromatography (GPC) (Figure 3).

Based on the GPC results, $10 \%, 50 \%$ and $90 \%$ elution mass of the valonea tannins were $817 \pm 12,3042 \pm 15$ and $17,469 \pm 257 \mathrm{~g} / \mathrm{mol}$, respectively. This indicated that $80 \%$ of the tannin molecules had a mass ranging from 817 to $17,469 \mathrm{~g} / \mathrm{mol}$. Furthermore, $50 \%$ valonea tannin molecules eluted earlier than tannic acid and $90 \%$ of the valonea tannin showed higher molecular weight than gallic acid. This indicated the average molecular weight of valonea tannin should be higher than the other two compounds. Based on the results from Kennedy's report, 50\% elution mass of tannin is in good agreement with the average molecular weight determined by other method [19]. Therefore, the $50 \%$ elution mass $(3042 \pm 15 \mathrm{~g} / \mathrm{mol})$ of the valonea tannin was taken for the following analysis. 


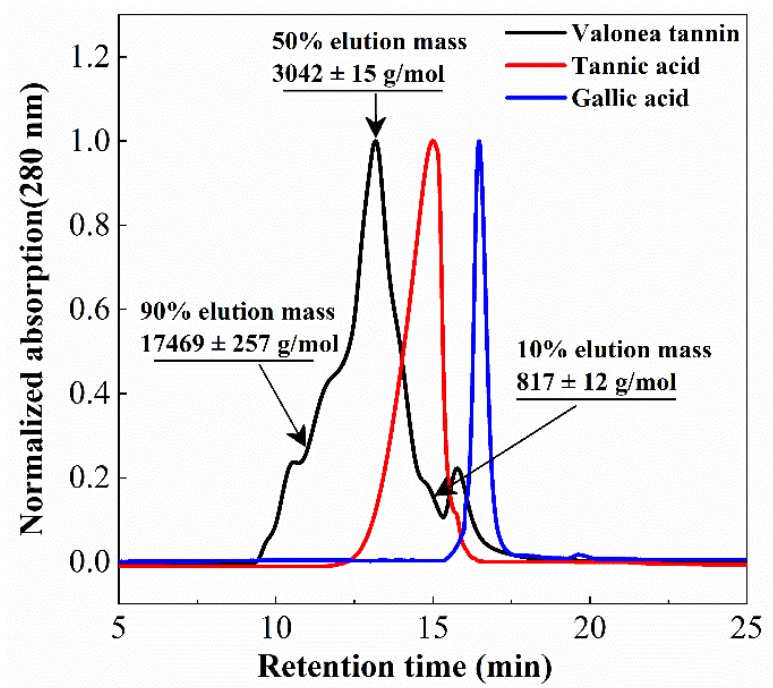

Figure 3. Gel permeation chromatogram $(280 \mathrm{~nm})$ showed the elution profile of valonea tannin, tannic acid and gallic acid, average molecular mass of valonea tannin is shown as the $50 \%$ elution mass.

\subsection{Tyrosinase Inhibition Activity of the Valonea Tannin}

Valonea tannin was assessed for tyrosinase inhibition to determine if this natural product may have value for commercial application as a whitening agent in cosmetic products or dermatologic medicines. Tannic acid and gallic acid were also assessed for tyrosinase inhibition for comparison as these compounds were: (1) all composed of pyrogallol moieties (Figure 2) that played critical roles in the enzyme inhibition processes [9]; (2) have molecular weights that differ to each other and are lower than valonea tannins (Figure 3); and (3) accepted as tyrosinase inhibitors with better performances than the commercial tyrosinase inhibitors [9].

The tyrosinase inhibition activities were assessed across a range of concentrations for valonea tannins as well as tannic and gallic acids. Inhibition was measured as an increase in absorbance over time (Figure S2). The $\mathrm{IC}_{50}$ values were calculated as the inhibitor concentration inducing a 50\% reduction in maximum absorbance and are presented in Table 2.

Table 2. Tyrosinase inhibition ability of the valonea tannin, tannic acid and gallic acid.

\begin{tabular}{ccccc}
\hline Sample & Valonea Tannin & Tannic Acid & Gallic Acid & Hydroquinone \\
\hline $\mathrm{IC}_{50}(\mathrm{mM})$ & $1.15 \pm 0.37$ & $4.00 \pm 0.10$ & $389.56 \pm 4.77$ & $1809.38 \pm 5.74$ \\
$\mathrm{IC}_{50}(\mathrm{~g} / \mathrm{L})$ & $3.50 \pm 0.11$ & $6.80 \pm 0.17$ & $66.23 \pm 0.81$ & $199.21 \pm 0.63$ \\
Fold $^{2}$ & - & 3.4 & 339 & \\
\hline
\end{tabular}

${ }^{1} \mathrm{IC}_{50}$ was the half maximal inhibitory concentration, data were expressed as mean of 3 replicates \pm standard deviation; Kruskal-Wallis test showed $p<0.05$, indicated significant differences between $\mathrm{IC}_{50}$ obtained from different samples. ${ }^{2}$ The fold was calculated through: Fold $=\mathrm{IC}_{50}$ of tannic acid or gallic acid/ $\mathrm{IC}_{50}$ of valonea tannin.

The $\mathrm{IC}_{50}$ values of the involved inhibitors followed a trend: valonea tannin $<$ tannic acid < gallic acid. This suggested that tyrosinase inhibition capability was, positively related to molecular weight, which is also in agreement with a conclusion obtained by condensed tannins with different molecular weights [15].

Gallic acid has previously been shown to have excellent tyrosinase inhibition ability with an $\mathrm{IC}_{50}$ value 100 -fold lower than kojic acid [24]. In the current study, the $\mathrm{IC}_{50}$ value of valonea tannin was 339-fold lower than gallic acid (Table 2), which indicated that the valonea tannin may has better tyrosinase inhibition ability than the commercial inhibitors. To explore why the valonea tannin showed such an outstanding tyrosinase inhibition ability, the inhibition mechanisms were studied and presented in the following sections. 


\subsection{The Kinetic Study of Tyrosinase Inhibition Mechanism}

To answer why valonea tannin has inhibition ability, kinetic characteristics of the inhibition reactions were studied to better understand the mechanism of action of valonea tannin's tyrosinase inhibition. The kinetic studies were applied and the results are provided in Figure 4.

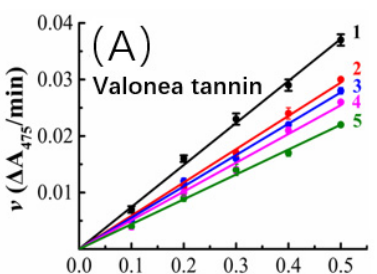

[E] $\mathrm{mg} / \mathrm{mL}$

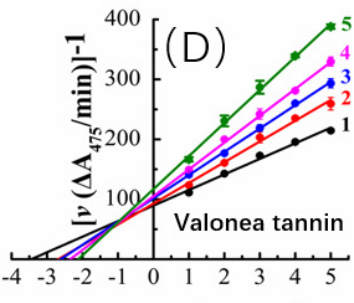

$[\mathrm{L}-\mathrm{DOPA}]^{-1} /(\mathbf{m M})^{-1}$

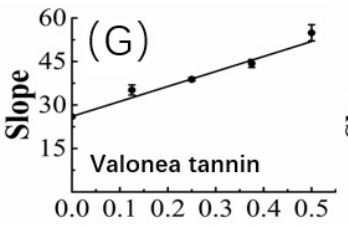

[I] $(\mathrm{mM})$

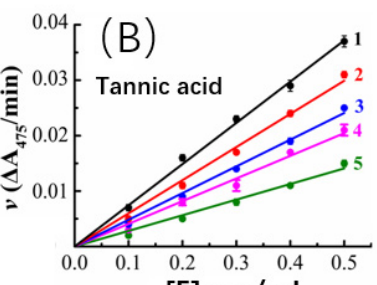

[E] $\mathrm{mg} / \mathrm{mL}$
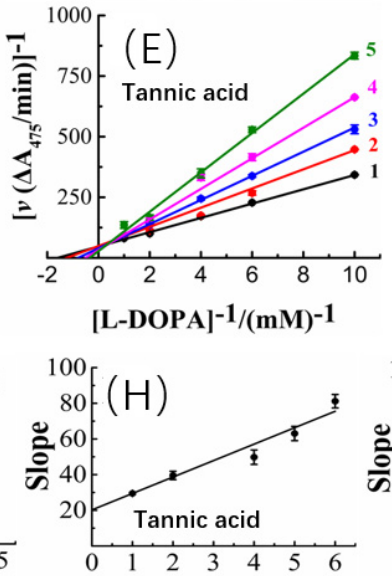

[I] (mM)

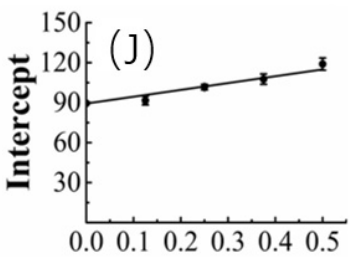

[I] $(\mathrm{mM})$

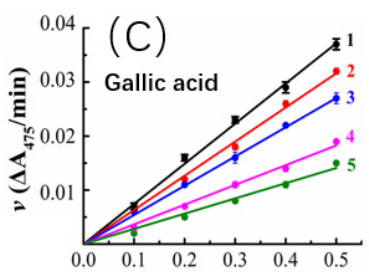

$[\mathrm{E}] \mathrm{mg} / \mathrm{mL}$
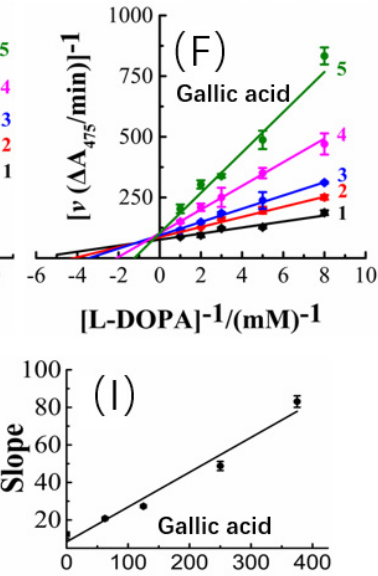

[I] (mM)

Figure 4. Tyrosinase concentration-reaction rate plots showed the valonea tannin (A), tannic acid (B) and gallic acid (C) reversibly inhibited tyrosinase activities (1 to 5, gradually increase the concentration of inhibitors); The Lineweaver-Burk plots of valonea tannin (D), tannic acid (E) and gallic acid (F); the plot of slope (or intercept) versus inhibitor concentrations of valonea tannin (G), tannic acid $(\mathbf{H})$ and gallic acid (I); the plot of intercept versus valonea tannin concentration for determining inhibition constants $\mathrm{K}_{\mathrm{IS}}(\mathrm{J})$.

The tyrosinase concentration-reaction rate plots showed that, with a constant valonea tannin concentration, the initial velocities linearly fitted with tyrosinase concentrations and the fitted lines all passed through origin of the axis (Figure 4A). Therefore, a deduction can be made as: despite varying valonea tannin concentrations, the reactions will continue proceeding until tyrosinase is eliminated completely from the reaction systems $([\mathrm{E}]=0)$. Based on the characteristics mentioned above, referencing the previous reports [16,25], the valonea tannin inhibition reaction was classified as a reversible type. As for tannic acid or gallic acid, their tyrosinase concentration-reaction rate plots also showed significant characteristics of the reversible type as well (Figure 4B,C), in agreement with the results obtained by previous research [26].

Based on the adjusted Michaelis-Menten equation [27], the Lineweaver-Burk plots of the reactions were obtained by analysing velocity under different valonea tannin con- 
centrations (Figure $4 \mathrm{D})$. It was evident that the inverse of the velocity $(1 / \mathrm{v})$ were all linearly fitted with the inverse of the substrate concentration $\left(\mathrm{R}^{2}\right.$ and $p$-values are shown in Table S4) while meanwhile it intersected in the second quadrant of the plot. Based on Waldrop's finding, these graphical characters indicated the maximum reaction speed (Vmax $=1$ /intersect on y-axis) and Michaelis's constant $\left(\mathrm{K}_{\mathrm{M}}\right)$ of the reactions were all affected with varying inhibitor concentrations [27]. Thus, the inhibition provided by valonea tannins belonged to a competitive-noncompetitive mixed type. In other words, the valonea tannin presents inhibition through either entering the active centre or binding on the surface (non-active centre) of tyrosinase. This is similar to the inhibition mechanism provided by condensed tannins [16]. In contrast to valonea tannins, the Lineweaver-Burk plots of the tannic acid and gallic acid showed different characteristics (Figure 4E,F). The fitted lines were intersected on y-axis, which indicated these compounds inhibit tyrosinase competitively, which is in agreement with a previous report [28].

Slopes and y-axis intercepts of the fitted Lineweaver-Burk lines were taken for secondary fittings, where they all were linearly fitted with inhibitor concentrations (Figure 4G-I). The slopes and y-axis intercepts of the new lines were calculated to obtain the inhibition constants of inhibitor-tyrosinase $\left(\mathrm{K}_{\mathrm{I}}\right)$ and inhibitor-tyrosinase-substrate complexes $\left(\mathrm{K}_{\mathrm{IS}}\right)$ (Figure $4 \mathrm{~J}$ ), respectively [27]. $\mathrm{K}_{\mathrm{I}}$ is the dissociation constant between inhibitor and enzyme, and $\mathrm{K}_{\mathrm{IS}}$ is the dissociation constant between inhibitor and the enzyme-substrate complex. The smaller the $\mathrm{K}_{\mathrm{I}}$ or $\mathrm{K}_{\mathrm{IS}}$ values provided by inhibitor, the better competition abilities to substrate were indicated [27].

In the current research, the $\mathrm{K}_{\mathrm{I}}$ and $\mathrm{K}_{\mathrm{IS}}$ values of the involved inhibitors followed a trend as: valonea tannin $\left(\mathrm{K}_{\mathrm{I}}\right)<$ valonea tannin $\left(\mathrm{K}_{\mathrm{IS}}\right)<$ tannic acid $\left(\mathrm{K}_{\mathrm{I}}\right)<$ gallic acid $\left(\mathrm{K}_{\mathrm{I}}\right)$ (Table 3). Indicated in comparison with tannic acid and gallic acid, the valonea tannin showed better competition ability than substrate. Furthermore, the higher the molecular weight of tested inhibitors, the better the competition ability that was shown. This trend is not only in agreement with the results observed from $\mathrm{IC}_{50}$, but also similar to the conclusions that were obtained from condensed tannins [29]. The results obtained from the kinetic study are summarized on Table 3.

Table 3. Effects of Valonea tannin on tyrosinase activities ${ }^{1}$.

\begin{tabular}{cccc}
\hline & Valonea Tannin & Tannic Acid & Gallic Acid \\
\hline Inhibition mechanism & Reversible & Reversible & Reversible \\
Inhibition type & Competitive-noncompetitive mixed & Competitive & Competitive \\
Inhibition constants $(\mathrm{mM})^{2}$ & $\mathrm{~K}_{\mathrm{IS}=1.68 \pm 0.18}$ & $\mathrm{~K}_{\mathrm{I}}=1.97 \pm 0.32$ & $\mathrm{~K}_{\mathrm{I}}=56.58 \pm 3.65$ \\
& $\mathrm{~K}_{\mathrm{I}}=0.51 \pm 0.05$ & & \\
\hline
\end{tabular}

\footnotetext{
${ }^{1}$. Data are expressed as mean of 3 replicates \pm standard deviation, the model fitting results, including $\mathrm{R}^{2}$ and $p$ values, are shown in Table S4; Kruskal-Wallis test showed $p<0.05$, indicated significant differences between $\mathrm{K}_{\mathrm{I}}$ and $\mathrm{K}_{\mathrm{IS}}$ obtained from different samples. 2. $\mathrm{K}_{\mathrm{I}}$ was the inhibition constant, $\mathrm{K}_{\mathrm{IS}}$ was the inhibition constant in enzyme-substrate complex, $\mathrm{K}_{\mathrm{IS}}$ was attribute to the valonea tannin-tyrosianse-L-DOPA complex.
}

To find more information to explain why valonea tannin showed a better competition ability to substrate, the mechanism of valonea tannin-tyrosinase interactions were investigated using fluorescence and isothermal titration calorimetry (ITC) as described below.

\subsection{Fluorescence and Thermodynamic Characters of the Valonea Tannin-Tyrosinase Interaction}

The cause of the observed improved competition ability of valonea tannin was explored using fluorescence quenching (Figure 5) and isothermal titration calorimetry (ITC) (Figure 6). 

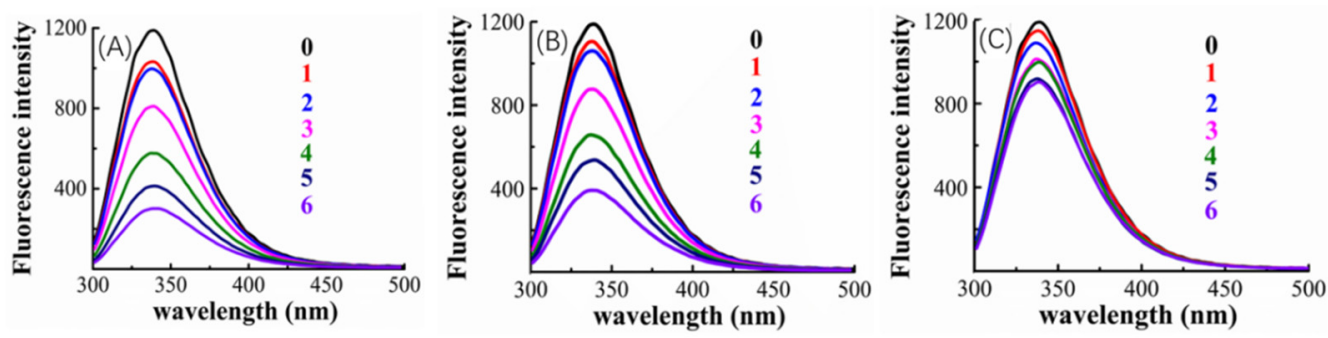

Figure 5. Fluorescence emission spectra of mushroom tyrosinase in solutions combined with valonea tannin (A), tannic acid (B) and gallic acid (C) with a range of concentrations $(0=0 \mu \mathrm{M}$ control; 1-6 = 5, 10, 25, 50, 75 and $100 \mu \mathrm{M}$, respectively).
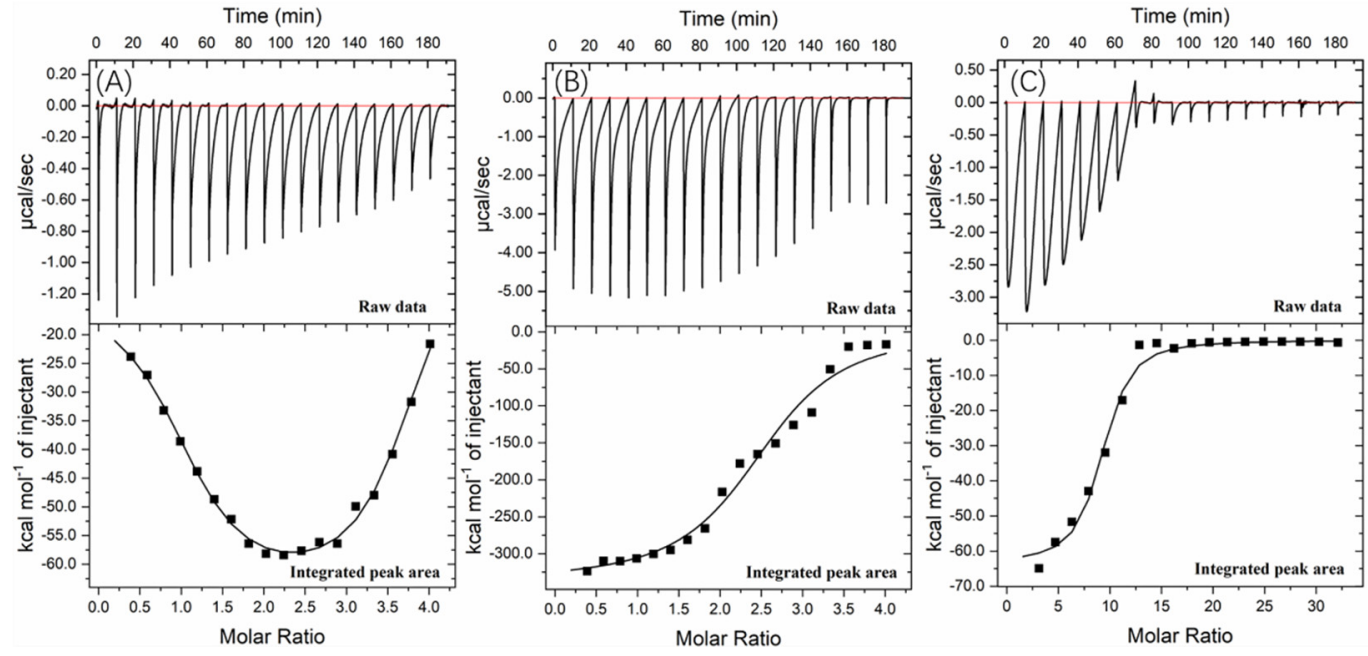

Figure 6. Interaction of (A) valonea tannin, (B) tannic acid and (C) gallic acid with tyrosinase studied by ITC at $25^{\circ} \mathrm{C}$ showed the thermogram and binding isotherm, the titration curve from valonea tannin was fitted using two sets of sites binding model while tannic acid and gallic acid were fitted by one set of sites.

The tryptophan inside tyrosinase is the fluorophore that has florescence emitting with a $280 \mathrm{~nm}$ excitation wavelength [30]. The tyrosinase-inhibitor binding process may lead to a fluorescence quenching induced by the structural changes of the tyrosinase around tryptophan, consequently, fluorescence quenching was used to provide primary information about inhibitor-tyrosinase interaction [30].

Figure 5 indicated that, the tyrosinase showed a florescence emission at $340 \mathrm{~nm}$, and fluorescence quenching appeared after adding inhibitors (valonea tannin, tannic acid or gallic acid, respectively). Greater concentrations of inhibitors also increased the observed quenching, which implies that the quenching may be induced by the interaction between inhibitors and tyrosinase.

The quenching phenomenon can be classified into dynamic and static types, while the former one does not involve chemical interaction between fluorophore and quencher, only the static quenching refers to binding interactions [29]. Based on the study provided by Van De Weert and Stella [29], the Stern-Volmer quenching rate constant $\left(\mathrm{K}_{\mathrm{q}}\right)$ and apparent binding constant $\left(\mathrm{K}_{\mathrm{a}}\right)$ were consequently obtained by linear regressions of the Stem-Volmer equation and double log Stem-Volmer equation (Figure S3) and shown in Table 4.

The fluorescence analysis results showed that $\mathrm{K}_{\mathrm{q}}$ presented by valonea tannin-tyrosinase complex was significantly higher than the maximum scatter collision quenching rate constant for dynamic quenching $\left(2 \times 10^{10} \mathrm{~L} / \mathrm{mol} / \mathrm{s}\right)$ [29], meanwhile their maximum emission wavelengths were observed as constant at $340 \mathrm{~nm}$ (Table 4). This phenomenon implied a non-covalent bond was formed between valonea tannin and tyrosinase [29], which is in agreement with the results obtained through hydrolysable tannin-protein interactions [31]. As for the tannic acid and gallic acid, the tyrosinase showed similar quenching characters. This further suggests that these interactions were non-covalent as 
previously reported for interactions between tyrosinase and tannic acid [32]. The quenching efficiency as well as the $\mathrm{K}_{\mathrm{a}}$ of the involved inhibitors followed: valonea tannin > tannic acid $>$ gallic acid. These results preliminary indicated the valonea tannin maybe more strongly bound to tyrosinase than the other two inhibitors [29].

Table 4. Information of valonea tannin-tyrosinase binding process obtained by fluorescence spectra ${ }^{1}$.

\begin{tabular}{cccc}
\hline & Valonea Tannin & Tannic Acid & Gallic Acid \\
\hline Maximum emitting wavelength $(\mathrm{nm})$ & 340 & 340 & 340 \\
Quenching efficiency $(\%)^{2}$ & $74.3 \pm 0.2$ & $66.5 \pm 0.4$ & $24.2 \pm 0.4$ \\
$\mathrm{~K}_{\mathrm{q}}\left(\times 10^{13}\right)$ & $2.85 \pm 0.00$ & $1.94 \pm 0.00$ & $0.28 \pm 0.00$ \\
Quenching type & Static & Static & Static \\
Linkage type & Non-covalent & Non-covalent & Non-covalent \\
$\mathrm{K}_{\mathrm{a}}(\mathrm{L} / \mathrm{mol}) \times 10^{5}$ & $2.23 \pm 0.00$ & $1.32 \pm 0.00$ & $0.73 \pm 0.00$ \\
\hline
\end{tabular}

${ }^{1}$ Data are expressed as mean of 3 replicates \pm standard deviation, the model fitting results, including $\mathrm{R}^{2}$ and $p$ values, are shown in Table S4; $\mathrm{K}_{\mathrm{q}}$ and $\mathrm{K}_{\mathrm{a}}$ was Stern-Volmer quenching rate constant and apparent binding constant, respectively; Kruskal-Wallis test showed $p<0.05$ for quenching efficiency, $\mathrm{K}_{\mathrm{q}}$ and $\mathrm{K}_{\mathrm{a}}$, respectively, indicated significant differences between different samples. ${ }^{2}$ Calculated as: Quenching efficiency $=100 \times$ emission at $340 \mathrm{~nm}$ (with $10 \mu \mathrm{M}$ inhibitor) $/$ emission at $340 \mathrm{~nm}$ (without inhibitor).

Further information about the valonea tannin-tyrosinase binding process was further investigated using ITC analysis. The tyrosinase is a typical globular protein which has complicated stereochemical structures, and tannin is a natural product with polydispersity, therefore tannin-protein interactions are believed to be complex [33]. ITC enables measurement of the binding strength of tannin-protein interactions by quantifying the thermodynamic changes of complex reactions [34]. The ITC curves of valonea tannin, tannic acid and gallic acid titrated into tyrosinase are shown in Figure 6. These negative peaks, shown on the raw data, were attributed to the negative enthalpy from tannin-tyrosinase interaction. In other words, the interaction was exothermic [33]. These titration signals were typical of protein-ligand interactions, resulting from the combination of hydrogen bonding and hydrophobic interactions as has been previously seen in the initial section of ITC curves from earlier reports [34].

The rapid reduction of exothermic peaks $(\Delta \mathrm{H}<0)$ upon titration indicated the valonea tannins showed a strong affinity to tyrosinase. With increasing valonea tannin addition, the number of available binding sites decreased, which resulted in the associated enthalpy changes decreasing. The titration curve was found to better fitted with the "two sets of binding sites" model, which implied the two kinds of binding sites were occupied by valonea tannins. On the contrary, the titration curves obtained from tannic acid and gallic acid showed better fitted with the "one set of binding sites" model. The inhibition mechanism results classified valonea tannin as a competitive-noncompetitive mixed type, while classified gallic acid and tannic acid were competitive types (Table 3). This also indicated the valonea tannin bound on both active and non-active sites of the tyrosinase, while gallic acid and tannic acid bound on the active sites further confirming the proposed inhibition mechanism.

Enthalpy change $(\Delta \mathrm{H})$ was calculated from the area under each ITC curve, and entropy changes (T $\Delta S$ ), stoichiometry (molar ratio of inhibitor to site, expressed as " $n$ " [34]) and equilibrium binding constants $(\mathrm{K})$ were calculated from the graphical characters of the curve using the Origin 7.0 software package. Results are shown in Table 5. The negative $\Delta \mathrm{H}$ values of valonea tannin-tyrosinase interaction indicating that interactions on these two sites were exothermic. The negative $\Delta \mathrm{H}$ and $\mathrm{T} \Delta \mathrm{S}$, observed from inhibitortyrosinase complexes, demonstrate both hydrophobic interactions and hydrogen bonding were essential for the binding [34]. 
Table 5. Information of valonea tannin-tyrosinase binding process obtained by isothermal titration calorimetry ${ }^{1}$.

\begin{tabular}{cccc}
\hline & Valonea Tannin & Tannic Acid & Gallic Acid \\
\hline$\Delta \mathrm{H}\left(\times 10^{4} \mathrm{cal} / \mathrm{mol}\right)$ & $-1.26 \pm 0.44($ site 1$)$ & $-33.62 \pm 1.11$ & $-6.34 \pm 0.23$ \\
$\mathrm{~T} \Delta \mathrm{S}\left(\times 10^{4} \mathrm{cal} / \mathrm{mol} / \mathrm{deg}\right)$ & $-6.66 \pm 0.22($ site 2$)$ & & -5.67 \\
$\mathrm{~K}\left(\times 10^{5}\right)$ & $-5.90($ site 1$)$ & -32.79 & \\
& $70.6 \pm 3.0($ site 1$)$ & $2.0 \pm 0.5$ & $0.9 \pm 0.3$ \\
$\mathrm{n}$ & $4.3 \pm 0.8($ site 2$)$ & & \\
& $1.02 \pm 0.04($ site 1$)$ & $2.50 \pm 0.05$ & \\
\hline
\end{tabular}

${ }^{1}$ Standard deviations were based on the accuracy of the curve fit to the data and obtained by Origin software package, estimated thermodynamic binding parameters for the interaction of tyrosinase and inhibitors at $298 \mathrm{~K}$ $\Delta \mathrm{H}$ and $\mathrm{T} \Delta \mathrm{S}$ was the change in enthalpy and change in entropy, respectively, while $\mathrm{n}$ was the stoichiometry and $\mathrm{K}$ was the binding constant.

The valonea tannin showed $\mathrm{K}$ values $70.6 \pm 3.0\left(\times 10^{5}\right)$ at binding site 1 and $4.3 \pm 0.8\left(\times 10^{5}\right)$ at binding site 2 , which were significantly higher than the tannic or gallic acids, suggesting stronger binding. This is likely to relate to the greater molecular weight of the valonea tannin that enabled quicker and stronger inhibition to tyrosinase. As expected, the $\mathrm{n}$ values of valonea tannins were smaller than (or similar to) tannic acid and gallic acid. This phenomenon could be attributed to the stronger steric hinderance, larger hydrodynamic volumes and higher binding strength presented by valonea tannin, which were obtained from GPC, inhibition kinetic and fluorescence study. This result supports the trend observed in apparent binding constant $\left(\mathrm{K}_{\mathrm{a}}\right.$, from Stern-Volmer quenching) and inhibition constant in enzyme-substrate complex ( $\mathrm{K}_{\mathrm{IS}}$, from Michaelis-Menten kinetic) in this study, as well as a previous hypotheses that considers molecular weight as a key influence of tannin-protein interaction [35].

\subsection{Molecular Docking Analysis}

Molecular docking modelling was performed to provide insight to the specific tyrosinase inhibition activity of valonea tannin. As revealed by ${ }^{13} \mathrm{C} N M R$, the valonea tannins were composed of galloyl and HHDP as structural units. Thereby the gallic acid and HHDP were chosen as ligand models and applied for molecular docking analysis. For the docking results from each ligand-tyrosinase interaction, 20 complexes with different docking poses (also with lowest docking energies) were collected, among which the complexes with lowest energies are shown on Figure 7.

Molecular docking results indicated the model molecules (including gallic acid and HHDP) bind with tyrosinase at the active centre via hydrogen bonding [36]. Two hydrogen bonds were observed (Asn260 and His61) in the gallic acid-tyrosinase complex. As for HHDP, six hydrogen bonds were formed via His85, Asn81 and His244 inside the active centre. As for the tannic acid-tyrosinase complex, more hydrogen bonds were observed (Figure 7C). Thr187, His285, Cys83, His244, Ser282, Tyr65 and Arg268 were shown participating in the interaction; meanwhile eight hydrogen bonds were formed.

The results from molecular docking not only visualized the active site bindings which were observed from ITC and fluorescence analyses, but also discovered the interaction between copper ions and gallic or tannic acid. The valence states of these copper ions not only determine the type of activity showed by tyrosinase (diphenol or monophenol) but also believed to influence the activity of tyrosinase in catalytic cycles [37]. Therefore, the copper ion chelating and antioxidant ability of the valonea tannin were assessed and presented in the following section. 


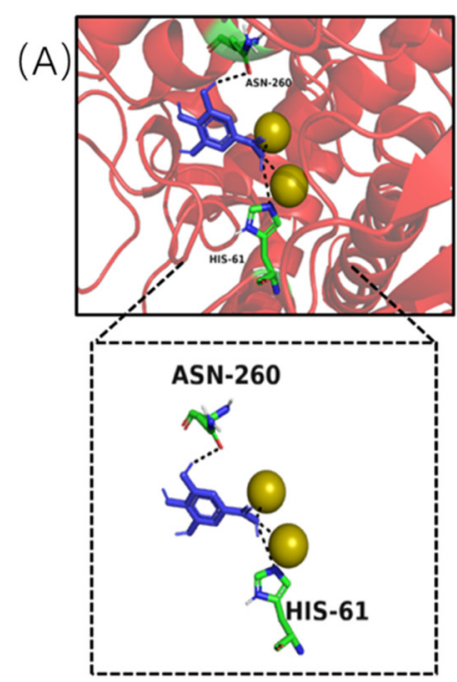

(B)

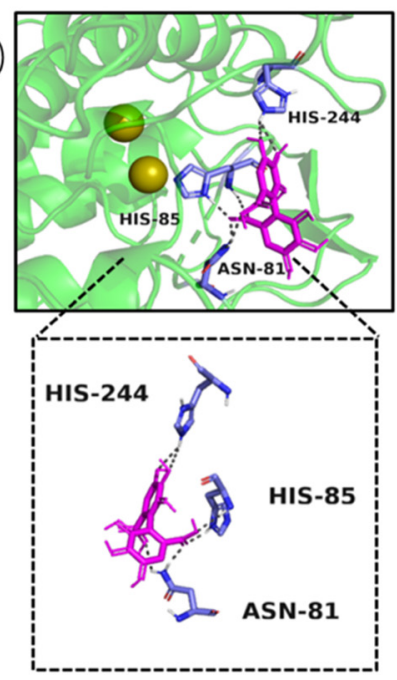

(C)

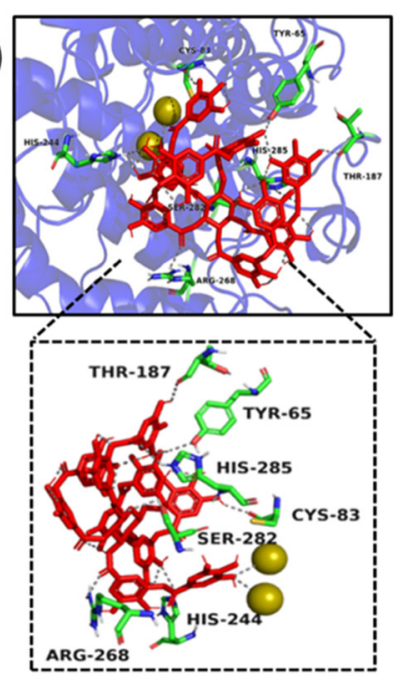

Figure 7. Complexes formed by tyrosinase and ligands and observed by molecular docking, including gallic acid-tyrosinase (A), HHDP-tyrosinase (B) and tannic acid-tyrosinase (C), the yellow and spheroidal icons were copper ions inside active central of the tyrosinase, the dotted lines were hydrogen bond formed between ligand and tyrosinase.

\subsection{Copper Ion Chelating and Antioxidant Abilities}

To further explore the inhibition mechanism proposed by the molecular docking studies, copper chelation and antioxidant analyses were also conducted (Table 6).

Table 6. Copper ion chelating and antioxidant abilities provided by valonea tannin, tannic acid and gallic acid ${ }^{1}$.

\begin{tabular}{cccc}
\hline & $\mathbf{C u}^{2+}$ Chelating (\%) & DPPH $\left.\mathbf{~ I C ~}_{\mathbf{5 0}} \mathbf{~ m M}\right)$ & ABTS $^{+}\left(\mathbf{I C}_{\mathbf{5 0}} \mathbf{~ m M}\right)$ \\
\hline Valonea tannin & $56.61 \pm 0.66$ & $0.051 \pm 0.002$ & $0.040 \pm 0.000$ \\
Tannic acid & $56.24 \pm 0.10$ & $0.043 \pm 0.001$ & $0.043 \pm 0.002$ \\
Gallic acid & $52.17 \pm 0.53$ & $0.322 \pm 0.004$ & $0.253 \pm 0.001$ \\
Ascorbic acid & - & $0.683 \pm 0.009$ & $0.713 \pm 0.012$ \\
\hline
\end{tabular}

${ }^{1}$ Data are expressed as mean of 3 replicates \pm standard deviation; Kruskal-Wallis test showed $p<0.05$ for $\mathrm{Cu}^{2+}$ Chelating, DPPH ${ }^{\circ}$ and $\mathrm{ABTS}^{+}{ }^{+}$, respectively, indicated significant differences between different samples.

The adjacent hydroxyl groups on galloyl moieties, enabled the hydrolysable tannin to chelate with metal ions and form aggregates and eventually precipitate [35]. Copper ion chelating ability was analysed using inductively coupled plasma (ICP) spectroscopy and shown in Table 6 . The results indicated that, after reacting with valonea tannin, large quantities of copper ions were precipitated and only $56.61 \pm 0.66 \%$ were remaining in the aqueous phase. This implied chelating with copper ion was another pathway of tyrosinase inhibition, in agreement with the phenomenon observed through molecular docking.

Chemicals with antioxidant activities are known to also have tyrosinase inhibition activities, not only because the tyrosinase catalysed L-DOPA to DOPA quinone reaction is basically an oxidation reaction, but also because the antioxidants may have an impact on the oxidation state of copper ions thereby becoming a hindrance in catalytic cycles of tyrosinase [37]. The DPPH and $\mathrm{ABTS}^{+}$scavenging abilities of valonea were compared to that of a known antioxidant, ascorbic acid (Table 6). Valonea tannin provided significantly lower $\mathrm{IC}_{50}$ values than ascorbic acid, which indicated substantial antioxidant capability that may also contribute to the tyrosinase inhibition ability, as previously noted for ascorbic acid [38].

In the current study, the tyrosinase inhibition activity of the inhibitors followed: valonea tannin $>$ tannic acid $>$ gallic acid. This trend repeatedly appeared in the results observed from tyrosinase binding analysis, as for the antioxidant and copper chelating abilities, the valonea tannin still showed better performance than the gallic acid and ascorbic acid but was similar to tannic acid (Table 6). Therefore, the outstanding tyrosinase inhibition provided by valonea tannins is basically attribute to its tyrosinase binding ability. 


\section{Materials and Methods}

\subsection{Extraction and Purification of Valonea Tannins}

Acorn caps (valonea, $600 \mathrm{~g}$ ) were collected from Valonia Oak trees (Quercus macrolepis) in Wuming (108 $16^{\prime} 27.34^{\prime \prime}$ E, $23^{\circ} 8^{\prime} 36.66^{\prime \prime} \mathrm{N}$, South China) in 2019. Valonea were washed with distilled water, air-dried at $25^{\circ} \mathrm{C}$ and ground into a fine powder using a plant tissue pulveriser (800A, Jinfeng Machinery Factory, Yongkang, China). Tannins were extracted from the powder $(100 \mathrm{~g})$ using $70 \%$ acetone: water solution $(2.0 \mathrm{~L})$ in a temperaturecontrolled shake incubator (THZ-C-1, Taicang experimental equipment factory, Hebei, China) with rotation speed at $30 \mathrm{rpm}, 25^{\circ} \mathrm{C}$ for $8 \mathrm{~h}$. After extraction, the valonea residue was removed via filter paper filtration, and acetone removed by rotary evaporation under reduced pressure $\left(35^{\circ} \mathrm{C}\right)$ to obtain a crude aqueous extract $(140 \mathrm{~mL})$. Lipids were removed from the aqueous extract by liquid-liquid separation via the addition of dichloromethane $(1: 1, v: v)$. Finally, the residual organic solvent was removed from the aqueous extract by rotary evaporation $\left(35^{\circ} \mathrm{C}\right.$ ) and the extract lyophilized to obtain an $80 \mathrm{~g}$ crude extract of powdered valonea tannins.

Crude valonea extracts ( $1 \mathrm{~g}$ in $10 \mathrm{~mL} 50 \% \mathrm{MeOH}$ solution) was purified with Sephadex LH-20 (Cytiva, Switzerland), as previously described [18]. Briefly, the Sephadex LH-20 column $(\varphi=3.5 \mathrm{~cm}$, bed volume $260 \mathrm{~mL})$ was equilibrated with $50 \% \mathrm{MeOH}(1 \% v / v$ formic acid) prior to loading the extract. Sugars and simple phenolics were removed using 50\% MeOH solution (5 L, flow rate $10 \mathrm{~mL} / \mathrm{min}$ ) and purified tannin eluted with $70 \%$ acetone $(1.5 \mathrm{~L})$, dried via rotary evaporation $\left(35^{\circ} \mathrm{C}\right)$ followed by lyophilization to obtain the purified valonea tannin powder $(240 \mathrm{mg})$. Purity of the tannin extract was confirmed using MALDI-TOF MS analysis, which demonstrated the absence of polysaccharides, proteins and lipids (Figure S5). The tannin purity was also tested by a methyl cellulose precipitation assay [39] and the results showed tannin concentration was $81.85 \pm 0.93 \%$ (standard curve is shown in Figure S6).

\subsection{Characterization of Valonea Tannin Structure}

Characterization of the purified tannin structure was achieved using Nuclear Magnetic Resonance (NMR) spectroscopy and the average molecular mass measured using gel permeation chromatography (GPC). For the NMR analysis, purified valonea tannin powder (30 mg in $750 \mu \mathrm{L} \mathrm{1:1,v/v,} \mathrm{CD}_{4} \mathrm{O}: \mathrm{D}_{2} \mathrm{O}$ ) ${ }^{13} \mathrm{C}$ NMR spectra were obtained using an Ascend $400 \mathrm{MHz}$ NMR spectrometer (Bruker, Switzerland) [20], $1.36 \mathrm{~s}$ acquisition time, $20.80 \mu \mathrm{s}$ dwell time, sweep width 24,038 Hz, frequency $100.60 \mathrm{MHz}$, relaxation delay $2 \mathrm{~s}$, receiver gain 203. Power level for pulse was set as $66 \mathrm{~W}$ and $90^{\circ}$ high power pulse was set at $10.57 \mu$ s. The ${ }^{13} \mathrm{C}$ NMR spectra were also obtained for standard samples of gallic acid (Aladdin Biochemical Technology Co., LTD, Shanghai, China) and tannic acid (Macklin Biochemical Technology Co., LTD, Shanghai, China), and chemical shifts were assigned (Figure S1). GPC was used to obtain the average molecular mass of the purified tannin as previously described $[18,19]$. Briefly, the tannin sample $(20 \mu \mathrm{L}$ in mobile phase $)$ was injected into $2 \times$ PLgel GPC columns in tandem $(300 \times 7.5 \mathrm{~mm}, 5 \mu \mathrm{m}, 100 \AA$ followed by $10^{4} \AA$ ) on an HPLC (Agilent 1100 , Palo Alto, USA) and protected by a guard column of the same material $(50 \times 7.5 \mathrm{~mm}, 5 \mu \mathrm{m})$ using a mobile phase of dimethylformamide solution (1\% acetic acid, $5 \%$ water and $0.15 \mathrm{M}$ lithium chloride) at $1 \mathrm{~mL} / \mathrm{min}$, column temperature $50{ }^{\circ} \mathrm{C}$, with detection at $280 \mathrm{~nm}$. The average molecular mass of valonea tannin was obtained by comparing elution time with a standard curve made by isolated grape skin tannins with molecular weight $2035 \mathrm{~g} / \mathrm{mol}, 5016 \mathrm{~g} / \mathrm{mol}, 7993 \mathrm{~g} / \mathrm{mol}$ and $17,674 \mathrm{~g} / \mathrm{mol}$, respectively. These grape tannins were prepared in accordance with our previous report [18]. The molecular weights of the grape tannins were determined with phloroglucinolysis in accordance with Kennedy's report [19].

\subsection{Tyrosinase Inhibition Activity Assessment and Inhibition Type Analysis}

Tyrosinase inhibition activity was evaluated as previously described [17] with L-DOPA as the substrate and the enzyme activity calculated by monitoring DOPA-quinone 
formation. Tyrosinase (EC 1.14.18.1, from mushroom) and L-DOPA (both from Aladdin Biochemical Technology Co., LTD, Shanghai, China) were dissolved in the sodium phosphate buffer (PBS, $50 \mathrm{mM}$ sodium phosphate in distil water, $\mathrm{pH}=6.8$, same as below), respectively, to obtain L-DOPA solution $(0.5 \mathrm{mM})$ and tyrosinase solution $(0.4 \mathrm{mg} / \mathrm{mL})$. Valonea tannin was prepared in water to a range of concentrations $(0 \mathrm{mM}, 0.2 \mathrm{mM}$, $0.4 \mathrm{mM}, 0.6 \mathrm{mM}, 0.8 \mathrm{mM}, 1.0 \mathrm{mM}, 1.3 \mathrm{mM}$ and $1.5 \mathrm{mM})$. For the inhibition assays, valonea tannin solutions $(50 \mu \mathrm{L})$ at each concentration were mixed with L-DOPA solution $(1 \mathrm{~mL})$ and heated in a water bath $\left(30^{\circ} \mathrm{C}\right)$ for $10 \mathrm{~min}$. Tyrosinase solution $(50 \mu \mathrm{L})$ was then added to each solution, mixed and an aliquot $(300 \mu \mathrm{L})$ immediately transferred into a 96-well plate. Absorbances were measured at $475 \mathrm{~nm}$ at the beginning $(0 \mathrm{~min})$ and end $(10 \mathrm{~min})$ of the reactions using a microplate reader (HTX, Bior Tek Synergy, Vermont, USA). During the analysis, the temperature was kept constant at $30^{\circ} \mathrm{C}$ by using a temperature controller equipped on the microplate reader. Reaction solution without tannin was used as negative control. The inhibition rate was calculated in accordance with Equation (1).

$$
\text { Inhibition rate }(\%)=\left[\left(\mathrm{A}_{2}-\mathrm{A}_{1}\right)-\left(\mathrm{B}_{2}-\mathrm{B}_{1}\right)\right] /\left(\mathrm{A}_{2}-\mathrm{A}_{1}\right) \times 100 \%
$$

where $A_{1}$ and $A_{2}$ represented the absorbance of the control at the beginning and end of the reaction; $B_{1}$ and $B_{2}$ represented the absorbance of the sample at beginning and end of the reaction, respectively.

The extent of inhibition was calculated using the obtained inhibition rate-inhibitor concentration plots (Figure S2) and expressed as the half maximal inhibitory concentration ( $\mathrm{IC}_{50}$ ).

Inhibition type was analysed based on the kinetic characteristics of the DOPA-quinone formation processes, which is concomitant with valonea tannins. The reversible-irreversible assessment was provided as previously described [16] with modifications. The initial velocities of DOPA-quinone formations were tested in reaction solutions with a constant L-DOPA concentration $(0.5 \mathrm{mM})$, and different valonea tannin $(0 \mathrm{mM}, 0.125 \mathrm{mM}, 0.25 \mathrm{mM}$, $0.375 \mathrm{mM}$ and $0.5 \mathrm{mM})$ and tyrosinase concentrations $(0.1 \mathrm{mg} / \mathrm{mL}, 0.2 \mathrm{mg} / \mathrm{mL}, 0.3 \mathrm{mg} / \mathrm{mL}$, $0.4 \mathrm{mg} / \mathrm{mL}$ and $0.5 \mathrm{mg} / \mathrm{mL}$ ). The absorbances of reaction solutions were recorded at $475 \mathrm{~nm}$ and the initial velocities were taken and expressed as $\Delta \mathrm{A} / \mathrm{min}$.

The competitive-noncompetitive assessment was performed in accordance with a previous report [25]. Briefly, initial velocities (recorded at $475 \mathrm{~nm}$ ) of reactions were taken from solutions prepared using a constant tyrosinase concentration $(0.1 \mathrm{mg} / \mathrm{mL})$, and different valonea tannin $(0 \mathrm{mM}, 0.125 \mathrm{mM}, 0.25 \mathrm{mM}, 0.375 \mathrm{mM}$ and $0.5 \mathrm{mM})$ and L-DOPA concentrations ( $1 \mathrm{mM}, 0.5 \mathrm{mM}, 0.33 \mathrm{mM}, 0.25 \mathrm{mM}$ and $0.20 \mathrm{mM}$ ). The Michaelis-Menten equation was then adjusted to fit Lineweaver-Burk plot as Equation (2) [27]:

$$
(1 / \mathrm{V})=\left(\mathrm{K}_{\mathrm{M}} / \mathrm{V}_{\max }\right) \times(1 /[\mathrm{S}])+\left(1 / \mathrm{V}_{\max }\right)
$$

where [S] was the substrate concentration, $V$ was the corresponding initial velocity. $K_{M}$ and $V_{\max }$ were the Michaelis's constant and maximum reaction speed, respectively, which were obtained from the vertical and horizontal intercept from the Lineweaver-Burk plot.

The inhibition constant $\left(\mathrm{K}_{\mathrm{I}}\right)$ and inhibition constant in enzyme-substrate complex $\left(\mathrm{K}_{\mathrm{IS}}\right)$ were obtained by secondary plot of inhibitor concentration with slope and intercept of the Lineweaver-Burk plot as Equations (3) and (4) [27]:

$$
\begin{gathered}
\text { Slope }=\mathrm{K}_{\mathrm{M}} / \mathrm{V}_{\max }\left(1+[\mathrm{I}] / \mathrm{K}_{\mathrm{I}}\right) \\
\text { Intercept }=1 / \mathrm{V}_{\max }\left(1+[\mathrm{I}] / \mathrm{K}_{\mathrm{IS}}\right)
\end{gathered}
$$

The tyrosinase inhibition activity of tannic acid and gallic acid were also measured along with the inhibition type analysis for comparison with valonea tannin.

\subsection{Fluorescence Quenching Analysis of Tyrosinase in the Presence of Valonea Tannins}

Fluorescence quenching was used to measure the change in tyrosinase activity in the presence of valonea tannins. The analysis was conducted in accordance with a published 
protocol [30], and the method was adjusted as follows: The fluorescence intensities were recorded by a fluorescence spectrometer (Hitachi F-7000, Kyoto, Japan) equipped with a xenon lamp source. A $280 \mathrm{~nm}$ excitation wavelength, $240 \mathrm{~nm} / \mathrm{min}$ scan speed, $5 \mathrm{~nm}$ emission slit width and $2.5 \mathrm{~nm}$ excitation slit width were chosen for the analysis. In this assay, valonea tannins with different concentrations $(0,5,10,25,50,75$ and $100 \mu \mathrm{M})$ were mixed with tyrosinase solution at a fixed concentration $(0.4 \mathrm{mg} / \mathrm{mL})$. The prepared samples were then transferred for fluorescence analysis, while intensities were recorded from 300 to $500 \mathrm{~nm}$. In the current study, emissions at $340 \mathrm{~nm}$ were chosen for quenching related calculations since the maximum fluorescence appeared at this wavelength. Quenching was calculated using the Stern-Volmer [29] Equation (5):

$$
\mathrm{F}_{0} / \mathrm{F}=1+\mathrm{K}_{\mathrm{sv}}[\mathrm{Q}]=1+\mathrm{K}_{\mathrm{q}} \tau_{0}[\mathrm{Q}]
$$

where $\mathrm{F}$ and $\mathrm{F}_{0}$ were the fluorescence intensities (at $340 \mathrm{~nm}$ ) with or without valonea tannin. [Q] was the tannin concentration and $\mathrm{K}_{\mathrm{sv}}$ is the Stern-Volmer quenching constant. The $\mathrm{K}_{\mathrm{sv}}$ was the slope calculated from the linear regression plot of $F_{0} / F$ against [Q]. $K_{q}$ was the biomolecular quenching rate constant. $\tau_{0}$ was the average lifetime of the fluorophore in the absence of the tannin $\left(\tau_{0}=10^{-8} \mathrm{~s}\right)$ [29].

As for the static quenching, the $\mathrm{F}_{0}, \mathrm{~F}$ and [Q] were taken for apparent binding constant calculation based on double log Stern-Volmer [29] Equation (6):

$$
\log \left[\left(\mathrm{F}_{0}-\mathrm{F}\right) / \mathrm{F}\right]=\log \mathrm{K}_{\mathrm{a}}+\operatorname{nlog}[\mathrm{Q}]
$$

where $\mathrm{K}_{\mathrm{a}}$ was the apparent binding constant that was obtained by the slope of $\log \left[\left(\mathrm{F}_{0}-\mathrm{F}\right) / \mathrm{F}\right]$ versus log [Q] plots. Double log plotting needed restrict requisite otherwise false $n$ values could be obtained [29]. Therefore, in the current study, the $n$ value was not taken into consideration. The fluorescence quenching of tyrosinase was analysed with gallic acid and tannic acid for comparison, the Stern-Volmer plot $\left(\mathrm{F}_{0} / \mathrm{F}\right.$ against [Q]) and double log Stern-Volmer plot $\left(\log \left[\left(F_{0}-F\right) / F\right]\right.$ versus $\left.\log [Q]\right)$ are provided in Supplementary Information S3.

\subsection{Isothermal Titration Calorimetry Analysis}

Isothermal Titration Calorimetry (ITC) analysis was conducted as previously described [34] but modified as follows: Tyrosinase solution (50 $\mathrm{MM}$ PBS buffer $50 \mathrm{mM}$, $\mathrm{pH}=6.8)$ added to the calorimeter cell $(200 \mu \mathrm{L})$ on an ITC instrument (ITC 200, MicroCal, Northampton, MA, USA) instrument and equilibrated at $25^{\circ} \mathrm{C}$ for $30 \mathrm{~min}$ under a rotation speed of $1000 \mathrm{r} / \mathrm{min}$. To calculate the thermal character during binding, valonea tannin solution ( $1 \mathrm{mM}$ in PBS buffer $50 \mathrm{mM}, \mathrm{pH}=6.8$ ) was injected into the sample cell at $25^{\circ} \mathrm{C}$. The injection volume, number of injections and the spacing time between injections were set as $2 \mu \mathrm{L}, 18$ and $600 \mathrm{~s}$, respectively. During analysis, the valonea tannin solution was injected into the reference cell which contained a buffer solution; the thermal behaviour was recorded and used as a negative control.

Peak interpretation, stoichiometry $(n)$, the binding constant $(K)$, change in enthalpy $(\Delta \mathrm{H})$ and change in entropy $(\Delta S)$ were calculated on Origin 7.0 software package (Northampton, MA, USA), while changes in Gibbs free energy were calculated based on a previously report [40]. A "two set of identical sites" model was applied for valonea tannins. The tannic acid-tyrosinase reaction and gallic acid-tyrosinase reaction were also analysed as described above, and the data were fitted with the "one set of identical sites". All standard deviations shown in the ITC results were based on the accuracy of the curve fit to the data and obtained by Origin software package.

\subsection{In Silico Molecule Docking}

In silico molecule docking models were performed using AutoDock Vinasoftware (DeLano Scientific LLC, Palo Alto, CA, USA) to provide an understanding of the mechanism of tyrosinase inhibition by valonea tannins. The crystallographic structure of the tyrosinasetropolone complex from Agaricus bisporus (PDB: 2Y9X, obtained by X-ray diffusion) was 
obtained from RCSB Protein Databank. Then, tropolone and water molecules on tyrosinase were removed, followed by a polar hydrogen atoms addition, a missing atoms correction and a Gasteiger charges assignment [41]. Gallic acid, HHDP and tannic acid were constructed with Chem Draw 17.0 (Cambridge, UK) and taken as ligands. Structures of the ligands were subsequentially geometry optimized with an MM2 force field to minimize the energy and obtain the preferential conformations [41].

In accordance with Heitz's report [41], the blind docking simulations were performed within a grid box which was centred on the geometric central position of the tropolone on tyrosinase complex ( $\mathrm{x}, \mathrm{y}, \mathrm{z}$ : $-7.392,-24.898,-39.626)$. The grid box was set to have a $30 \times 30 \times 30$ size with grid spacing of $0.1 \mathrm{~nm}$. The energy range was set at 10, while exhaustiveness was 20. Other operator weights for crossover, mutation and elitism were default parameters. A semi-flexible docking was chosen for all processes, while the sophisticated gradient optimization method in its local optimization was employed to search for the preferential conformations, and the empirical scoring function was used for docking score calculation. The predicted binding energies were collected from 20 ligand-receptor complexes with lowest energies, from which the complex with the lowest binding energy was preserved and pose of the ligand, hydrogen bond and related amino acid residuals were analysed with PyMOL 2.2 (Schrödinger Inc, New York, NY, USA).

\subsection{Antioxidant Activity Analysis}

The antioxidant activity of the valonea tannin was evaluated using scavenging assays with 3-ethylbenzthiazolin-6-sulfonic acid (ABTS ${ }^{+}$) as well as 2,2-diphenyl-1-picrylhydrazyl (DPPH'). The DPPH' scavenging ability was analysed in accordance with Brand-Williams's report [42]. DPPH' solutions $(1.5 \mathrm{~mL}, 25 \mathrm{mg} / \mathrm{Lin}$ methanol) were mixed with $50 \mu \mathrm{L}$ valonea tannin solutions at different concentrations $(0 \mathrm{mM}, 0.02 \mathrm{mM}, 0.03 \mathrm{mM}, 0.04 \mathrm{mM}, 0.05 \mathrm{mM}$ and $0.06 \mathrm{mM}$ in methanol), and placed in the dark for $30 \mathrm{~min}$. After the reaction time, $300 \mu \mathrm{L}$ of the mixed solution was transferred into a 96 well microplate reader, and the absorbance measured at $517 \mathrm{~nm}$ and corrected using methanol. This method was used in place of the valonea tannins as a negative control.

The $\mathrm{ABTS}^{+}$scavenging ability was measured as previously described [43]. Briefly, $7 \mathrm{mM}$ ABTS and $2.45 \mathrm{mM}$ potassium persulfate were mixed and placed in the dark for $16 \mathrm{~h}$ (at $25{ }^{\circ} \mathrm{C}$ ) to form a stable oxidation state of $\mathrm{ABTS}^{+}$radical cations. $\mathrm{ABTS}^{+}$solution was then diluted with $80 \%$ ethanol to reach an absorbance of $0.700 \pm 0.05$ at wavelength $734 \mathrm{~nm}$. Valonea tannin solutions $(0.1 \mathrm{~mL})$ with different concentrations $(0 \mathrm{mM}, 0.02 \mathrm{mM}, 0.03 \mathrm{mM}$, $0.04 \mathrm{mM}, 0.05 \mathrm{mM}, 0.06 \mathrm{mM}$ and $0.07 \mathrm{mM}$, in $80 \%$ ethanol) were mixed with $3.9 \mathrm{~mL}^{\mathrm{ABTS}}{ }^{+}$ solution. After $6 \mathrm{~min}$ reaction (at $25^{\circ} \mathrm{C}$ ), $300 \mu \mathrm{L}$ of the mixed solution was transferred into a 96 well microplate and the absorbance at $734 \mathrm{~nm}$ was recorded, corrected with methanol. Methanol $(0.1 \mathrm{~mL})$ was used to replace the valonea tannins as a negative control.

The $\mathrm{DPPH}^{-}$and $\mathrm{ABTS}^{+}$free radical scavenging rates were calculated by using Equation (7):

$$
\text { Free radical elimination rate }(\%)=\left[\left(\mathrm{A}_{1}-\mathrm{A}_{2}\right) / \mathrm{A}_{1}\right] \times 100
$$

where $A_{1}$ was the absorbance of control, and $A_{2}$ was the absorbance of sample.

The $\mathrm{IC}_{50}$ was obtained using the linear regression of a valonea tannin concentration to free radical elimination rate plot. Following the method described above, $\mathrm{IC}_{50}$ values were also obtained for gallic acid, tannic acid and ascorbic acid for comparison.

\subsection{Inductively Coupled Plasma-Optical Emission Spectroscopy (ICP-OES)}

The $\mathrm{Cu}^{2+}$-binding capacity of valonea tannin was measured using ICP-OES as previously described [44]. Valonea tannin solution $(1 \mathrm{mg} / \mathrm{mL}$, in distilled water) and copper sulphate solution $\left(0.5 \mathrm{M}\right.$, in distilled water) were mixed $(1: 1, \mathrm{v}: \mathrm{v})$, incubated for $3 \mathrm{~h}\left(37^{\circ} \mathrm{C}\right)$ and centrifuged for $30 \mathrm{~min}(4390 \mathrm{~g})$. The supernatant was subjected to an ICP-OES analysis (Agilent 5110, Palo Alto, CA, USA) and the remnant $\mathrm{Cu}^{2+}$ concentration measured. A $12.0 \mathrm{~L} / \mathrm{min}$ plasma flow rate, $1.5 \mathrm{~L} / \mathrm{min}$ auxiliary flow rate and $0.70 \mathrm{~L} / \mathrm{min}$ nebulizer flow 
rates were provided during the analysis, while sample uptake and instrument stabilization delay were $15 \mathrm{~s}$. Gallic acid and tannic acid were also used to react with copper sulphate and remnant $\mathrm{Cu}^{2+}$ were quantified following above method for comparison.

\subsection{Statistical Analysis}

Non-parametric test (Kruskal-Wallis) was performed to determine differences between the experimental samples (triplicated) using Minitab 18 (Minitab Inc., State College, PA, USA). The model fitting results are all applied in Supplementary Information S4.

\section{Conclusions}

Elucidation of the isolated valonea tannin revealed the tannin was composed of gallic acid, HHDP and glucose with an average molecular weight of $3042 \pm 15 \mathrm{Da}$. Tyrosinase inhibition ability provided by valonea tannin was 334 times greater than that of gallic acid and 3.4 times higher than tannic acid. Mechanism studies suggested that the observed enzyme inhibition was driven by a combination of hydrogen bonding and hydrophobic interactions which involved non-selective binding to the surface of tyrosinase, resulting in a competitive and non-competitive mixed inhibition mechanism. Antioxidant activity and copper ion chelating ability of valonea tannin also contributed to tyrosinase inhibition. These results suggest that extracted valonea tannins may be of value as a whitening agent in cosmetics or dermatological medicines as an effective replacement for commercial tyrosinase inhibitors.

Supplementary Materials: The following are available online, Figure S1. C NMR spectrum of valonea tannin, tannic acid and gallic acid; Figure S2. The tyrosinase inhibition activity evaluated by conducting the catalysis reaction with different inhibitor concentrations. Figure S3. Stern-Volmer plot $\left(\mathrm{A}, \mathrm{F}_{0} / \mathrm{F}\right.$ against $\left.[\mathrm{Q}]\right)$ and double $\log$ Stern-Volmer plot $\left(\mathrm{B}, \log \left[\left(\mathrm{F}_{0}-\mathrm{F}\right) / \mathrm{F}\right]\right.$ versus $\left.\log [\mathrm{Q}]\right)$ obtained from calculating valonea tannin, tannic acid and gallic acid induced fluorescence quenching of the tyrosinase. Table S4. The model fitting results from liner regression of the kinetic and fluorescence quenching analysis. Figure S5. The MALDI TOF MS spectra of the purified valonea tannin. Figure S6. The standard curve for methyl cellulose precipitation assay.

Author Contributions: Conceptualization, B.T.; methodology, B.T. and J.L.; formal analysis, J.L.; investigation, Y.L.; resources, X.H.; writing-original draft preparation, J.L. and B.T.; writing-review and editing, J.M.M.; visualization, X.H.; supervision, B.T.; project administration, B.T.; funding acquisition, B.T. All authors have read and agreed to the published version of the manuscript.

Funding: This research is funded by the Natural Science Foundation of Guangdong Province, China (2020A1515011357), the Department of Education of Guangdong Province, China (2018KQNCX081) and the Research and Development Start-up Foundation (NTF18031).

Institutional Review Board Statement: Not applicable.

Informed Consent Statement: Not applicable.

Data Availability Statement: The data presented in this study are available on reasonable request from the corresponding author.

Acknowledgments: Stella Kassara and Keren Bindon from the Australian Wine Research Institute are thanked for their assistance in providing standard samples for GPC analysis. Yizhao Ren from Northwest Agriculture and Forest University is thanked for his help and support during GPC analysis. Thanks also to Jinwei Zhang from Sichuan University for support in the valonea sample collection.

Conflicts of Interest: The authors declare no conflict of interest.

Sample Availability: Samples of the compounds are not available from the authors. 


\section{References}

1. Romani, A.; Ieri, F.; Turchetti, B.; Mulinacci, N.; Vincieri, F.; Buzzini, P. Analysis of condensed and hydrolysable tannins from commercial plant extracts. J. Pharm. Biomed. Anal. 2006, 41, 415-420. [CrossRef] [PubMed]

2. Li, C.; Wang, W.; Mu, Y.; Zhang, J.; Zhang, S.; Li, J.; Zhang, W. Structural Properties and Copolycondensation Mechanism of Valonea Tannin-Modified Phenol-formaldehyde Resin. J. Polym. Environ. 2018, 26, 1297-1309. [CrossRef]

3. Ren, Z.; Yu, F.; Gao, H.; Chen, Z.; Peng, Y.; Liu, L. Selective Separation of Fluorite, Barite and Calcite with Valonea Extract and Sodium Fluosilicate as Depressants. Minerals 2017, 7, 24. [CrossRef]

4. Wang, H.; Wang, L. Developing a bio-based packaging film from soya by-products incorporated with valonea tannin. J. Clean. Prod. 2017, 143, 624-633. [CrossRef]

5. Onem, E.; Gulumser, G.; Akay, S.; Yesil-Celiktas, O. Optimization of tannin isolation from acorn and application in leather processing. Ind. Crops Prod. 2014, 53, 16-22. [CrossRef]

6. Pillaiyar, T.; Manickam, M.; Namasivayam, V. Skin whitening agents: Medicinal chemistry perspective of tyrosinase inhibitors. J. Enzym. Inhib. Med. Chem. 2017, 32, 403-425. [CrossRef] [PubMed]

7. Iozumi, K.; Hoganson, G.E.; Pennella, R.; Everett, M.A.; Fuller, B.B. Role of Tyrosinase as the Determinant of Pigmentation in Cultured Human Melanocytes. J. Investig. Dermatol. 1993, 100, 806-811. [CrossRef] [PubMed]

8. Lianza, M.; Mandrone, M.; Chiocchio, I.; Tomasi, P.; Marincich, L.; Poli, F. Screening of ninety herbal products of commercial interest as potential ingredients for phytocosmetics. J. Enzym. Inhib. Med. Chem. 2020, 35, 1287-1291. [CrossRef] [PubMed]

9. Khan, M.T.H. Molecular design of tyrosinase inhibitors: A critical review of promising novel inhibitors from synthetic origins. Pure Appl. Chem. 2007, 79, 2277-2295. [CrossRef]

10. Zolghadri, S.; Bahrami, A.; Khan, M.T.H.; Munoz-Munoz, J.; Garcia-Molina, F.; Garcia-Canovas, F.; Saboury, A.A. A comprehensive review on tyrosinase inhibitors. J. Enzym. Inhib. Med. Chem. 2019, 34, 279-309. [CrossRef]

11. Weiss, R.M.; Del Fabbro, E.; Kolisang, P. Cosmetic ochronosis caused by bleaching creams containing $2 \%$ hydroquinone. South Afr. Med J. 1990, 77, 373.

12. A Ibrahim, Z.; Gheida, S.F.; El Maghraby, G.M.; E Farag, Z. Evaluation of the efficacy and safety of combinations of hydroquinone, glycolic acid, and hyaluronic acid in the treatment of melasma. J. Cosmet. Dermatol. 2015, 14, 113-123. [CrossRef] [PubMed]

13. Schofield, P.; Mbugua, D.; Pell, A. Analysis of condensed tannins: A review. Anim. Feed. Sci. Technol. 2001, 91, 21-40. [CrossRef]

14. Sarikurkcu, C.; Kocak, M.S.; Tepe, B.; Uren, M.C. An alternative antioxidative and enzyme inhibitory agent from Turkey: Robinia pseudoacacia L. Ind. Crops Prod. 2015, 78, 110-115. [CrossRef]

15. Chai, W.-M.; Shi, Y.; Feng, H.-L.; Xu, L.; Xiang, Z.-H.; Gao, Y.-S.; Chen, Q.-X. Structure Characterization and Anti-tyrosinase Mechanism of Polymeric Proanthocyanidins Fractionated from Kiwifruit Pericarp. J. Agric. Food Chem. 2014, 62, 6382-6389. [CrossRef] [PubMed]

16. Chai, W.-M.; Wang, R.; Wei, M.-K.; Zou, Z.-R.; Deng, R.-G.; Liu, W.-S.; Peng, Y.-Y. Proanthocyanidins Extracted from Rhododendron pulchrum Leaves as Source of Tyrosinase Inhibitors: Structure, Activity, and Mechanism. PLoS ONE 2015, 10, e0145483. [CrossRef]

17. Manosroi, A.; Jantrawut, P.; Akazawa, H.; Akihisa, T.; Manosroi, J. Biological activities of phenolic compounds isolated from galls of Terminalia chebula Retz. (Combretaceae). Nat. Prod. Res. 2010, 24, 1915-1926. [CrossRef] [PubMed]

18. Teng, B.; Hayasaka, Y.; Smith, P.A.; Bindon, K.A. Effect of Grape Seed and Skin Tannin Molecular Mass and Composition on the Rate of Reaction with Anthocyanin and Subsequent Formation of Polymeric Pigments in the Presence of Acetaldehyde. J. Agric. Food Chem. 2019, 67, 8938-8949. [CrossRef]

19. A Kennedy, J.; Taylor, A.W. Analysis of proanthocyanidins by high-performance gel permeation chromatography. J. Chromatogr. A 2003, 995, 99-107. [CrossRef]

20. Xu, M.; Zha, Z.-J.; Qin, X.-L.; Zhang, X.-L.; Yang, C.-R.; Zhang, Y.-J. Phenolic Antioxidants from the Whole Plant of Phyllanthus urinaria. Chem. Biodivers. 2007, 4, 2246-2252. [CrossRef]

21. Ozgunay, H.; Sari, O.; Tozan, M. Molecular investigation of valonea tannin. J. Am. Leather Chem. Assoc. 2007, 102, $154-157$.

22. Abdalla, S.; Pizzi, A.; Bahabri, F.; Ganash, A. Analysis of Valonia Oak (Quercus aegylops) Acorn Tannin and Wood Adhesives Application. BioResources 2015, 10, 7165-7177. [CrossRef]

23. Chung, K.-T.; Wong, T.Y.; Wei, C.-I.; Huang, Y.-W.; Lin, Y. Tannins and Human Health: A Review. Crit. Rev. Food Sci. Nutr. 1998, 38, 421-464. [CrossRef]

24. Chang, T.-S. An Updated Review of Tyrosinase Inhibitors. Int. J. Mol. Sci. 2009, 10, 2440-2475. [CrossRef] [PubMed]

25. Waldrop, G.L. A qualitative approach to enzyme inhibition. Biochem. Mol. Biol. Educ. 2009, 37, 11-15. [CrossRef]

26. Si, C.-L.; Wu, L.; Shen, T.; Huang, X.-F.; Du, Z.-G.; Ren, X.-D.; Luo, X.-G.; Hu, W.-C. Recovery of Low-molecular Weight Galloyltannins from Agricultural Residue of Juglans sigillata Dode Seed Husks and their Tyrosinase Inhibitory Effect. BioResources 2014, 9, 2226-2236. [CrossRef]

27. Whiteley, C.G. Enzyme kinetics: Partial and complete uncompetitive inhibition. Biochem. Educ. 2000, 28, 144-147. [CrossRef]

28. Kubo, I.; Kinst-Hori, I.; Nihei, K.-I.; Soria, F.; Takasaki, M.; Calderón, J.S.; Céspedes, C.L. Tyrosinase Inhibitors from Galls of Rhus javanica Leaves and Their Effects on Insects. Zeitschrift für Naturforschung C 2003, 58, 719-725. [CrossRef]

29. Van de Weert, M.; Stella, L. Fluorescence quenching and ligand binding: A critical discussion of a popular methodology. J. Mol. Struct. 2011, 998, 144-150. [CrossRef] 
30. Chai, W.-M.; Wei, M.-K.; Wang, R.; Deng, R.-G.; Zou, Z.-R.; Peng, Y.-Y. Avocado Proanthocyanidins as a Source of Tyrosinase Inhibitors: Structure Characterization, Inhibitory Activity, and Mechanism. J. Agric. Food Chem. 2015, 63, 7381-7387. [CrossRef] [PubMed]

31. Deaville, E.R.; Green, R.J.; Mueller-Harvey, I.; Willoughby, A.I.; Frazier, R.A. Hydrolyzable Tannin Structures Influence Relative Globular and Random Coil Protein Binding Strengths. J. Agric. Food Chem. 2007, 55, 4554-4561. [CrossRef]

32. Patil, S.; Sistla, S.; Jadhav, J. Interaction of small molecules with human tyrosinase: A surface plasmon resonance and molecular docking study. Int. J. Biol. Macromol. 2016, 92, 1123-1129. [CrossRef] [PubMed]

33. McRae, J.M.; Kennedy, J.A. Wine and Grape Tannin Interactions with Salivary Proteins and Their Impact on Astringency: A Review of Current Research. Molecules 2011, 16, 2348-2364. [CrossRef]

34. McRae, J.M.; Falconer, R.J.; Kennedy, J.A. Thermodynamics of Grape and Wine Tannin Interaction with Polyproline: Impiications for Red Wine Astringency. J. Agric. Food Chem. 2010, 58, 12510-12518. [CrossRef]

35. Haslam, E. Natural Polyphenols (Vegetable Tannins) as Drugs: Possible Modes of Action. J. Nat. Prod. 1996, 59, 205-215. [CrossRef]

36. Noh, H.; Lee, S.J.; Jo, H.-J.; Choi, H.W.; Hong, S.; Kong, K.-H. Histidine residues at the copper-binding site in human tyrosinase are essential for its catalytic activities. J. Enzym. Inhib. Med. Chem. 2020, 35, 726-732. [CrossRef] [PubMed]

37. Ramsden, C.A.; Riley, P.A. Mechanistic studies of tyrosinase suicide inactivation. Arkivoc 2010, 2010, 260-274. [CrossRef]

38. Ros, J.R.; Rodríguez-López, J.N.; García-Cánovas, F. Effect of 1-ascorbic acid on the monophenolase activity of tyrosinase. Biochem. J. 1993, 295, 309-312. [CrossRef]

39. Teng, B.; Petrie, P.; Smith, P.; Bindon, K. Comparison of water addition and early-harvest strategies to decrease alcohol concentration in Vitis vinifera cv. Shiraz wine: Impact on wine phenolics, tannin composition and colour properties. Aust. J. Grape Wine Res. 2020, 26, 158-171. [CrossRef]

40. Jelesarov, I.; Bosshard, H.R. Isothermal titration calorimetry and differential scanning calorimetry as complementary tools to investigate the energetics of biomolecular recognition. J. Mol. Recognit. 1999, 12, 3-18. [CrossRef]

41. Heitz, M.P.; Rupp, J.W. Determining mushroom tyrosinase inhibition by imidazolium ionic liquids: A spectroscopic and molecular docking study. Int. J. Biol. Macromol. 2018, 107, 1971-1981. [CrossRef] [PubMed]

42. Brand-Williams, W.; Cuvelier, M.E.; Berset, C. Use of a free radical method to evaluate antioxidant activity. LWT Food Sci. Technol. 1995, 28, 25-30. [CrossRef]

43. Re, R.; Pellegrini, N.; Proteggente, A.; Pannala, A.; Yang, M.; Rice-Evans, C. Antioxidant activity applying an improved ABTS radical cation decolorization assay. Free Radic. Biol. Med. 1999, 26, 1231-1237. [CrossRef]

44. Zeng, X.; Du, Z.; Ding, X.; Jiang, W. Characterization of the direct interaction between apple condensed tannins and cholesterol in vitro. Food Chem. 2020, 309, 125762. [CrossRef] [PubMed] 